\title{
PERLINDUNGAN HUKUM TERHADAP KOPERASI SIMPAN PINJAM BERKAITAN DENGAN KREDIT MACET DI KOTA DENPASAR *
}

\author{
Oleh: \\ I Putu Wira Kusumajaya** \\ Ni Putu Purwanti*** \\ Bagian Hukum Bisnis Fakultas Hukum Universitas Udayana
}

\begin{abstract}
Abstrak
Karya ilmiah ini membahas tentang perlindungan hukum terhadap dana koperasi simpan pinjam berkaitan dengan kredit macet di kota Denpasar dikarenkan kredit macet dapat berdampak pada dana yang dimiliki dan kesehatan koperasi simpan pinjam pada khususnya di kota Denpasar. Karya ilmiah ini menggunakan metode penelitian empiris, yaitu pendekatan dengan melihat suatu kenyataan hukum didalam masyarakat dari teori-teori hukum dengan melakukan penelitian secara langsung ke lapangan guna mendapatkan kebenaran yang akurat. Kesimpulan dari karya ilmiah ini koperasi simpan pinjam di kota Denpasar dalam prakteknya memberikan kredit dengan melakukan perjanjian disertakan dengan agunan. Perlindungan dana koperasi simpan pinjam merupakan tanggung jawab koperasi dan pengurus sebagai pelaksana kegiatan yang dilakukan oleh koperasi.
\end{abstract}

Kata Kunci: Perlindungan Hukum, Koperasi Simpan Pinjam, Kredit,

\begin{abstract}
This scientific paper discusses about legal protection toward the fund of savings and loan cooperative related to non-performing loan in Denpasar city since non-performing loan can have an impact on the fund it has and in particular the health of savings and loan cooperative in Denpasar city. This scientific paper used empirical research method, namely the approach by seeing a reality of law within society from theories of law by conducting research directly into the field in order to get accurate truth. The conclusion from this

* Makalah ini merupakan ringkasan skripsi

** I Putu Wira Kusumajaya adalah mahasiswa Fakultas Hukum Universitas Udayana. Korespondensi: Selfyour34@gmail.com

*** Ni Putu Purwanti,S.H.,M.H. Dosen Fakultas Hukum Universitas Udayana
\end{abstract}


scientific paper is that savings and loan cooperative in Denpasar city in practice grants a credit by making an agreement accompanied with collateral. The protection of the fund of savings and loan cooperative is the responsibility of agency and its management as the executor of activity performed in the agency.

Key words: Legal Protection, Savings and Loan Cooperative, Credit.

\section{PENDAHULUAN \\ 1.1 Latar Belakang}

Koperasi merupakan gerakan ekonomi rakyat yang dikelola menggunakan asas kekeluargaan dan asas kebersamaan ${ }^{2}$. Djojohadikoesoemo mendefinisikan bahwa koperasi ialah perkumpulan manusia seorang-seorang yang dengan sukanya sendiri hendak bekerja sama untuk memajukan ekonominya. ${ }^{3}$ Pada Pasal 1 angka 1 Undang-Undang No. 25 Tahun 1992 tentang Perkoperasian, yang dimaksud dengan koperasi yaitu "badan usaha yang beranggotakan orang seorang atau badan hukum koperasi dengan melandaskan kegiatannya berdasarkan prinsip koperasi sekaligus sebagai gerakan ekonomi rakyat yang berdasarkan atas asas kekeluargaan”.

Pasal 19 Peraturan Pemerintah Nomor 9 Tahun 1995 Tentang Pelaksanaan Usaha Simpan Pinjam oleh Koperasi yang hal. 135.

2 Janus Sidabalok, 2012, Hukum Perusahaan, Nuansa Aulia, Bandung,

${ }^{3}$ Hendrojogi,2015, Koperasi:Asas-Asas,Teori,Dan Praktik,Rajawali Pers,Jakarta,hal.21 
selanjutnya akan di sebut dengan Peraturan Pemerintah tentang Pelaksanaan Usaha Simpan Pinjam oleh Koperasi, kegiatan usaha koperasi simpan pinjam dan unit simpan pinjam adalah menghimpun simpanan koperasi berjangka dan tabungan koperasi dari anggota dan calon anggotanya, koperasi lain, dan/ anggotanya. Modal sendiri koperasi terdiri dari Simpanan Pokok yang harus disetorkan oleh setiap anggota pada saat mulai menjadi anggota koperasi, simpanan wajib adalah simpanan yang wajib dilakukan oleh setiap anggota secara berkala sesuai dengan ketentuan dalam angaran dasar koperasi yang bersangkutan, Cadangan dari sisa hasil usaha yang dialokasikan dan hibah dari pihak-pihak tertentu.

Dalam memberikan pinjaman, koperasi simpan pinjam dan unit simpan pinjam dilakukan secara sederhana tidak seperti bank namun masih memenuhi persyaratan prinsip dari pemberian kredit pola kesepakatan tertulis dalam rangka menjamin kepastian (hukum) apabila dikemudian hari terjadi sengketa diantara para pihak, maka kontrak tersebut akan dijadikan sebagai alat bukti tertulis guna mendalilkan tentang kebenaran dari hubungan yang telah terjalin beserta hak dan kewajiban masing-masing. ${ }^{4}$ Tetapi dalam setiap penagihan belum tentu dapat dengan mudah

${ }^{4}$ Ronald Saija, 2016, Penyalahgunaan Keadaan Oleh Negara Dalam Praktik Perjanjian Pada Kajian Hukum Privat, Kertha Patrika Fakultas Hukum Universitas Udayana, Denpasar, hal.182 
dilakukan, dapat dimungkinkan terjadinya kendala-kendala dalam proses penagihan dimana hal tersebut dapat mengakibat kredit macet. Kredit macet ini menggambarkan suatu situasi di mana persetujuan pengembalian kredit mengalami risiko kegagalan bahkan cenderung menuju ke arah di mana koperasi memperoleh rugi berdampak terhadap dana yang dimiliki dan kesehatan koperasi.

Dalam cara menyelesaikan problematika isu hukum ini diperlukan lapisan ilmu hukum seperti dogma hukum, yaitu adanya kesatuan yang relavan dengan masalah yang dihadapi. Teori hukum yaitu isunya mengandung konsep hukum dan filsafat hukum yang menyangkut asas-asas hukum. Seorang peneliti hukum lebih kritis terhadap putusan-putusan pengadilan di bandingkan dengan isu-isu sosial dalam masyarakat yang nyatanyatanya bukan penelitian hukum.

\subsection{Tujuan Penelitian}

Tujuan dari penelitian ini adalah untuk mengetahui perjanjian pemberian kredit yang dilakukan oleh koperasi simpan pinjam dan unit simpan pinjam serta perlindungan hukum terhadap koperasi berkaitan dengan kredit macet di kota Denpasar.

\section{ISI}




\subsection{Metode Penulisan}

Jenis penelitian yang digunakan dalam penelitian ini adalah penelitian empiris, yaitu penelitian di lapangan, guna meneliti pelaksanaan undang-undang dalam prakteknya di masyarakat. Penelitian hukum empiris adalah penelitian hukum mengenai pemberlakuan implemetasi ketentuan hukum normatif (kodifikasi, undang-undang, kontrak) secara in-action pada setiap peristiwa hukum tertentu yang terjadi dalam masyarakat. Jadi penelitian hukum empiris memfokuskan pada penelitian penerapan atau implementasi ketentuan hukum normatif (in-abstracto) pada peristiwa hukum tertentu (in-concreto) dan hasilnya. ${ }^{5}$

\subsection{Pembahasan}

\subsubsection{Pelaksanaan Perjanjian Kredit Terkait Pengunaan Anggota Koperasi Simpan Pinjam Di Kota Denpasar}

Perjanjian adalah suatu perbuatan dengan mana satu pihak mengikatkan dirinya terhadap satu orang atau lebih, pengertian ini terdapat pada Pasal 1313 KUHPerdata. Hal ini untuk memberikan kepastian hukum bagi para pihak yang mengikatkan dirinya. Perjanjian pinjaman merupakan hal yang harus dilaksanakan antara KSP/USP Koperasi dengan calon peminjam. Penanda tanganan perjanjian pinjaman ini baru dapat dilakukan setelah adanya keputusan dari hasil evaluasi permohonan Aditya Bakti, Bandung, hal. 134. 
pinjaman. ${ }^{6}$ Setiap orang yang membuat perjanjian terikat untuk memenuhi perjanjian tersebut karena perjanjian tersebut mengandung janji-janji yang harus dipenuhi dan mengikat para pihak $^{7}$ Perjanjian harus disimpan pada kantor koperasi dan salinannya dipegang oleh peminjam. Penanda tanganan perjanjian ini dilaksanakan di KSP/USP Koperasi yang bersangkutan.

Peraturan yang memberikan kewenangan kepada koperasi simpan pinjam untuk melakukan usaha simpan pinjam terdapat pada pasal 44 Undang-Undang Perkoperasian yang menjelesakan :

(1) Koperasi dapat menghimpun dana dan menyalurkanya melalui kegiatan usaha simpan pinjam dari dan untuk:

a. Anggota koperasi yang bersangkutan;

b. Koperasi lain dan/atau anggotanya.

(2) Kegiatan usaha simpan pinjam dapat dilaksanakan sebagai salah satu atau satu-satunya kegiatan usaha koperasi.

(3) Pelaksanaan kegiatan usaha simpan pinjam oleh koperasi diatur lebih lanjut dengan peraturan pemerintah.

6 Anindia Larasati,2013, Aspek Hukum Pemberian Pinjaman Oleh Koperasi Simpan Pinjam (KSP) Unit Simpan Pinjam (USP) Koperasi Pada Calon Anggota Berdasarkan Peraturan Pemerintah Nomor 9 Tahun 1995, Artikel Penelitian Mahasiswa Jurusan Perdata Ekonomi Fakultas Hukum Universitas Jember, hal. 4

${ }^{7}$ Ahmad Miru, 2014, Hukum Kontrak \& Perancangan Kontrak, PT. Raja Grafindo Persada, Jakarta, hal. 5. 
Kegiatan usaha simpan pinjam diatur lebih lanjut pada Peraturan Pemerintah tentang Kegiatan Usaha Simpan Pinjam Oleh Koperasi, di atur pada pasal 19 yang menjelsakan sebagai berikut :

(1) Kegiatan usaha koperasi simpan pinjam dan unit simpan pinjam adalah:

a. Mengimpun simpanan koperasi berjangka dan tabungan koperasi dari anggota dan calon anggotanya, koperasi lain dan atau anggotanya.

b. Memberikan pinjaman kepada anggota, calon anggotanya, koperasi lain dan atau anggotanya.

(2) Dalam memberikan pinjaman, koperasi simpan pinjam dan unit simpan pinjam wajib memegang teguh prinsip pemberian pinjaman yang sehat dengan memperhatikan penilaian kelayakan dan kemampuan pemohon pinjaman.

(3) Kegitan koperasi simpan pinjam dan unit simpan pinjam dalam melayani koperasi lain dan atau anggotanya sebagaimana dimaksud dalam ayat (1) dilakukan berdasarkan perjanjian kerjasama antar koperasi.

Kegiatan usaha simpan pinjam diatur lebih khusus lagi pada Peraturan Menteri tentang Usaha Simpan Pinjam Oleh Koperasi, 
pada pasal 22 Peraturan Menteri tentang Usaha Simpan Pinjam Oleh Koperasi menjelaskan :

(1) Pemberian nama produk simpanan koperasi berdasarkan rapat anggota.

(2) Simpanan diberikan imbalan dalam bentuk bunga yang besarnya ditetapkan rapat anggota.

(3) Koperasi simpan pinjam dan unit simpan pinjam koperasi wajib menjamin keamanan simpanan dan tabungan anggota, calon anggota, koperasi lain dan atau anggotanya.

Penelitian ini menggunakan 3 sampel koperasi simpan pinjam dan unit simpan pinjam di Denpasar, 3 koperasi ini adalah Koperasi Padang Pasar Kamboja, Koperasi Taman Sari, KPN Karya Bina Sejahtera. Ketiga koperasi ini hanya melayani anggotanya saja dan untuk bukan anggota dapat bergabung dengan koperasi untuk mendapatkan fasilitas yang disediakan oleh koperasi. Persyaratan untuk menjadi anggota koperasi tergantung pada kesepakatan pada rapat anggota. Koperasi Padang Pasar Kamboja hanya menerima anggota pada wilayah pasar kreneng dan pasar kumbasari, Koperasi Taman Sari untuk mendapatkan fasilitas koperasi minimal harus menjadi calon anggota dahulu sedangkan untuk KPN Karya Bina Sejahtera hanya menerima anggota dari pegawai negeri sipil lingkungan kerja Universitas Udayana. 
Pasal 19 ayat (2) Peraturan Pemerintah Pelaksanaan Kegiatan Usaha Simpan Pinjam Oleh Koperasi yang menjelaskan “ Dalam memberikan pinjaman, Koperasi Simpan Pinjam dan Unit Simpan Pinjam wajib memegang teguh prinsip memberikan pinjaman yang sehat dengan memperhatikan penilaian kelayakan dan kemampuan pemohon pinjaman”, dalam penjelasan Pasal 19 ayat (2) Peraturan Pemerintah Pelaksanaan Kegiatan Usaha Simpan Pinjam Oleh Koperasi yang dimaksud dengan azas pemberian pinjaman yang sehat adalah pemberian pinjaman yang didasarkan atas penilaian kelayakan dan kemampuan pemohon pinjaman koperasi simpan pinjam dan unit simpan pinjam.

Ketiga koperasi menerapkan prinsip kehati-hatian dan manajemen risiko dengan cara menggunakan perjanjian kepada anggota pemohon kredit. Koperasi Padang Pasar Kamboja dan Koperasi Taman Sari menggunakan perjanjian disertakan dengan agunan untuk pemberian kredit dan untuk pemberian kreditnya tidak lebih besar dari agunan yang disertakan pemohon. KPN Karya Bina Sejahtera tidak menggunakan agunan karena sistem pembayaran angsuran kredit melalui pemotongan gaji, untuk besaran kredit yang diberikan tergantung pada gaji yang dimiliki anggota dan maksimal 60 kali angsuran. 


\subsubsection{Perlindungan Terhadap Koperasi Simpan Pinjam Dalam Praktek Di Kota Denpasar}

Koperasi simpan pinjam dan unit simpan pinjam memiliki standar operasional manajemen untuk memberikan pelayanan yang prima bagi anggota, calon anggota, koperasi lain dan atau anggotanya. Ruang lingkup standar operasional manajemen usaha terdapat pada pasal 15 ayat (3) Peraturan Menteri tentang Usaha Simpan Pinjam Oleh Koperasi yang menyebutkan, standar operasional manajemen usaha terdiri dari :

a. Penghimpunan dan penyaluran dana.

b. Jenis pinjaman.

c. Persyaratan calon pinjaman.

d. Pelayanan pinjaman kepada unit lain.

e. Batasan maksimum pinjaman.

f. Biaya administrasi pinjaman.

g. Agunan.

h. Pengembalian dan jangka waktu pinjaman.

i. Analisis pinjaman.

j. Pembinaan anggota oleh KSP/USP.

k. Penangan pinjaman bermasalah.

Rapat anggota wajib dilaksanakan minimal 1 kali dalam setahun hal ini bertujuan untuk meminta pertanggungjawaban 
pengurus dan pengawas dalam hal kegiatan yang dilakukan oleh koperasi simpan pinjam/unit simpan pinjam koperasi. Rapat anggota adalah tempat dimana suara-suara anggota berkumpul dan diadakan pada waktu-waktu tertentu. ${ }^{8}$

Selain pertanggungjawaban yang dilakukan oleh koperasi simpan pinjam/unit simpan pinjam pemerintah juga melakukan pengawasan terhadap koperasi untuk memastikan bahwa koperasi itu sehat. Pemeriksaan Koperasi adalah serangkaian kegiatan mencari, mengumpulkan, dan mengolah data dan atau keterangan lain yang dilakukan oleh Pemeriksa Koperasi untuk membuktikan ada atau tidak adanya pelanggaran atas peraturan perundangundangan.Satgas koperasi adalah struktur aparatur sipil negara yang ditetapkan oleh Gubernur atau Bupati/Walikota untuk melaksakan kegiatan tugas dan fungsi pengawasan koperasi sesuai wilayah keanggotaan koperasi. Satgas koperasi berperan untuk mengawasi koperasi agar tidak menyimpang dari peraturan perundang-undangan yang berlaku. Peraturan Deputi Nomor 3 Tahun 2016 tentang Petunjuk Teknis Pelaksanaan Kegiatan Dan Anggaran Dekonsentrasi Dalam Rangka Memfasilitasi Kegiatan Teknis Program Penguatan Kelembagaan Koperasi Untuk Satgas Pengawasan Koperasi ,diharapkan dapat meminimalisir terjadinya penyimpangan dalam koperasi sehingga dapat menciptakan dan 
menumbuhkan iklim perekonomian di koperasi simpan pinjam/unit simpan pinjam. Menurut Pasal 5 Peraturan Deputi Tentang Satgas Pengawasan Koperasi, Tugas Satgas Koperasi Meliputi:

a) Pembinan pengendalian internal, Pengawasan dan Pemeriksaan Koperasi.

b) Melakukan kordinasi dalam rangka pelaksanaan pengawasan dan pemeriksaan koperasi secara obyektif.

c) Melakukan advokasi dalam rangka penyelesaian kasus-kasus koperasi serta perbaikan terhadap aspekaspek yang lemah dalam pengawasan agar dalam waktu 1 tahun sudah terjadi perbaikan dan peningkatan diwilayahnya.

d) Menertibkan kewajiban pelaporan oleh koperasi, melakukan tindak lanjut analisa dan teguran atau surat-surat pembinaan atas hasil analisa laporan.

Bapak I Gusti Ngurah Agung Sastrawan,S.E.,MM., Kepala Seksi Data dan Pengembangan Sumber Daya Manusia Koperasi Bidang Bina Lembaga Koperasi menjelaskan, koperasi yang mengalami penurunan aset dan modal serta penyaluran uang tidak sehat sehingga terjadi kredit macet maka satgas pengawas koperasi kota Denpasar akan melakukan pemeriksaan terhadap 
koperasi yang mengalami permasalahan tersebut. Ini merupakan pengawasan aktif yang dilakukan oleh satgas pengawas koperasi untuk memantau langsung koperasi yang berpotensi memiliki masalah. Sanski yang diberikan dapat berupa rehabilitasi kelembagaan, rehabilitasi usaha, bahkan sampai sanksi administrasi hal ini merupakan langkah refresif yang dilakukan oleh pemerintah pada koperasi simpan pinjam jika terjadi kredit macet dikarenakan wanprestasi dapat dilakukan penyelesaian secara litigasi dan non litigasi. Dikarenakan koperasi menganut asas kekeluargaan maka akan sebisa mungkin penyelesaian kredit macet dilakukan dengan cara kekeluargaan, yaitu dengan cara non litigasi salah satunya dengan cara Mediasi merupakan suatu proses negosiasi yang dibantu oleh pihak ketiga. Hal itu disebabkan para pihak yang tidak mampu menyelesaiakan sengketanya sendiri menggunakan jasa pihak ketiga yang bersikap netral untuk membantu mereka mencapai suatu kesepakatan ${ }^{9}$

Koperasi simpan pinjam dan unit simpan pinjam pada prakteknya di kota Denpasar menyelesaikan permasalahan kredit macet sebisa mungkin dengan cara non litigasi sedangkan untuk KPN Karya Bina Sejahtera dikarenan koperasi dengan sistem pembayaran angsuran menggunakan potong gaji jadi tidak akan terjadi kredit macet.

9 Mulyani Zulaeha, 2016, Mediasi Interest Based Dalam Penyelesaian Sengketa Tanah,Kertha Patrika,Denpasar, Hal. 157 


\section{Penutup}

\subsection{Simpulan}

1. Pelaksanaan perjanjian kredit terkait penggunaan dana koperasi simpan pinjam di kota Denpasar dilakukan secara tertulis dan tetap mengikuti syarat sahnya perjanjian pasal 1320 KUHPer. Pada koperasi simpan pinjam diperlukan agunan untuk menentukan besaran kredit yang akan diberikan, sedangkan untuk KPN Karya Bina Sejahtera tidak menggunakan agunan, pembayaran menggunakan sistem potong gaji dan untuk besarnya kredit yang diberikan tergantung dari gaji yang dimiliki anggota.

2. Perlindungan dana koperasi simpan pinjam dalam praktek di kota Denpasar dalam hal mencegah terjadinya kredit macet dan melakukan penanganan jika terjadi kredit macet dengan melaksanankan kegiatan usaha menggunakan standar oprasional manajemen yang terdapat pada Peraturan Menteri Tentang Usaha Simpan Pinjam Oleh Koperasi.

\subsection{Saran}

1. Disarankan agar Koperasi simpan pinjam selain diperkuat dengan menggunakan perjanjian tertulis juga harus memperhatikan besaran jaminan yang diberikan dan patut dilihat kesanggupan anggota dalam mengembalikan pinjaman yang akan diberikan nantinya. 
2. disarankan agar Koperasi simpan pinjam tidak menunggu hingga terjadinya kredit macet, pengurus koperasi secara aktif memantau anggotanya. Jika mulai terjadi keterlambatanketerlambatan dalam membayar angsuran kredit agar langsung ditinjau dan diberikan solusi.Hal ini bertujuan untuk menjaga kesehatan koperasi. 


\section{Daftar Pustaka}

\section{BUKU}

Abdulkadir Muhammad, 2004, Hukum dan Penelitian Hukum, PT. Citra Aditya Bakti, Bandung

Ahmad Miru, 2014, Hukum Kontrak \& Perancangan Kontrak, PT. Raja Grafindo Persada, Jakarta

Hendrojogi,2015, Koperasi:Asas-Asas,Teori,Dan Praktik,Rajawali Pers,Jakarta

I Ketut Artadi, I Dewa Nyoman Rai Asmara, 2014, Hukum Perjanjian Kedalam Perancangan Kontrak, Udayana University Press, Denpasar

Janus Sidabalok, 2012, Hukum Perusahaan, Nuansa Aulia, Bandung

Mulhadi, 2017, Hukum Perusahaan, PT Raja Grafindo Persada, Jakarta

\section{JURNAL}

Anindia Larasati,2013, Aspek Hukum Pemberian Pinjaman Oleh Koperasi Simpan Pinjam (KSP) Unit Simpan Pinjam (USP) Koperasi Pada Calon Anggota Berdasarkan Peraturan Pemerintah Nomor 9 Tahun 1995, Artikel Penelitian Mahasiswa Jurusan Perdata Ekonomi Fakultas Hukum Universitas Jember,Jember

I Gusti Ngurah Putu Putra Mahardika, Ibrahim R, 2013, Penyelesaian Kredit Macet Tanpa Jaminan Pada Koperasi, Kertha Semaya Fakultas Hukum Universitas Udayana, Denpasar

Mulyani Zulaeha, 2016, Mediasi Interest Based Dalam Penyelesaian Sengketa Tanah,Kertha Patrika,Denpasar 
Ronald saija, 2016, Penyalahgunaan Keadaan Oleh Negara Dalam Praktik Perjanjian Pada Kajian Hukum Privat, Kertha Patrika Fakultas Hukum Universitas Udayana, Denpasar

\section{PERATURAN PERUNDANG-UNDANGAN}

Kitab Undang-Undang Hukum Perdata (Burgerlijk Wetboek),, terjemahan Muzaki, 2013, Redaksi Aksara Sukses, Yogyakarta

Undang-Undang Nomor 25 tahun 1992 tentang Perkoperasian.

Peraturan Pemerintah Nomor 9 Tahun 1995 tentang Pelaksanaan Kegiatan Usaha Simpan Pinjam Oleh Koperasi.

Peraturan Menteri Koperasi Dan Usaha Kecil Dan Menengah Republik Indonesia Nomor 02 /Per/M.Kukm/ Ii /2017 Tentang Perubahan Atas Peraturan Menteri Koperasi Dan Usaha Kecil Dan Menengah Nomor 15/Per/M.Kukm/Ix/2015 Tentang Usaha Simpan Pinjam Oleh Koperasi. 